\title{
Mass mortality in bivalves and the intricate case of the Pacific oyster, Crassostrea gigas
}

\author{
Barbosa-Solomieu Valérie ${ }^{1}$, Renault Tristan ${ }^{2,{ }^{*}}$, Travers Marie-Agnes ${ }^{2}$
}

\begin{abstract}
${ }^{1}$ Université de Bretagne Occidentale, Direction Europe et International, Présidence, 3 rue des Archives, CS93837, 29238 Brest, CEDEX 3, France

${ }^{2}$ Ifremer, Unité Santé Génétique Microbiologie des Mollusques (SG2M), Laboratoire de Génétique et Pathologie des Mollusques Marins (LGPMM), 17390 La Tremblade, France
\end{abstract}

*Corresponding author : Tristan Renault, email address : Tristan.Renault@ifremer.fr

\begin{abstract}
:
Massive mortality outbreaks in cultured bivalves have been reported worldwide and they have been associated with infection by a range of viral and bacterial pathogens. Due to their economic and social impact, these episodes constitute a particularly sensitive issue in Pacific oyster (Crassostrea gigas) production. Since 2008, mortality outbreaks affecting C. gigas have increased in terms of intensity and geographic distribution. Epidemiologic surveys have lead to the incrimination of pathogens, specifically OsHV-1 and bacteria of the Vibrio genus, in particular Vibrio aestuarianus. Pathogen diversity may partially account for the variability in the outcome of infections. Host factors (age, reproductive status...) including their genetic background that has an impact on host susceptibility towards infection, also play a role herein. Finally, environmental factors have significant effects on the pathogens themselves, on the host and on the host-pathogen interaction. Further knowledge on pathogen diversity, classification, and spread, may contribute towards a better understanding of this issue and potential ways to mitigate the impact of these outbreaks.
\end{abstract}

\section{Graphical abstract :}

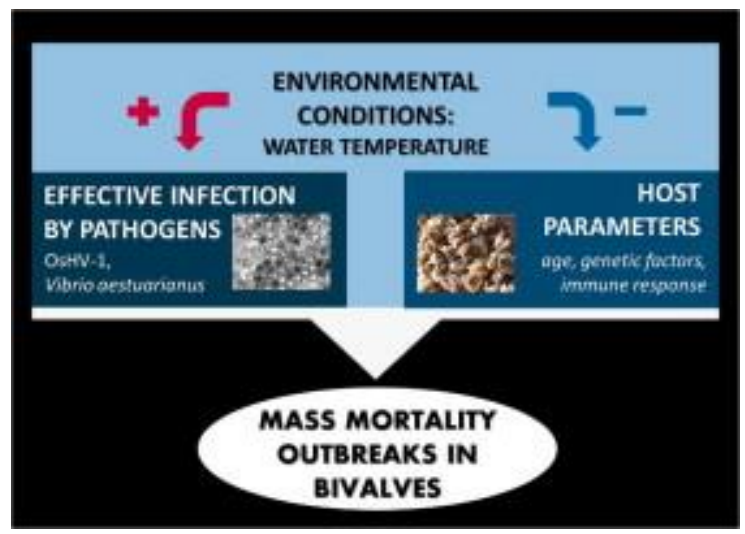




\section{Highlights}

- Bivalve production and trade are harmed by recurrent mortality outbreaks. In C. gigas, outbreaks have increased (intensity and geographic area) since 2008.. P Pathogens have been incriminated, particularly OsHV-1 and Vibrio aestuarianus. Host/pathogen and environmental factors affect the outcome of such infections. Mitigation of their impact requires additional data on pathogen diversity and spread..

Keywords : Pacific oyster, Spat, OsHV-1, Vibrio aestuarianus, Mortality

Valérie Barbosa Solomieu and Tristan Renault participated equally to this work and should be considered as primary co-authors 
1 Introduction: overview of massive mortality outbreaks in bivalves related to viral and bacterial infections

\subsection{Bivalve production and its vulnerability to pathogens}

Aquaculture is an expanding sector with both economic and social relevance: in 2012, global aquaculture production attained an all-time high of 90.4 million tons (US\$144.4 billion). Along with fisheries, aquaculture ensures the livelihoods of $10-12 \%$ of the world's population. The specific production of marine mollusks (oysters, mussels, clams, cockles, arkshells, and scallops) represents 13 million tons, with a value of US\$13.8 billion (FAOSTAT, 2012). However, the production and the trade of marine bivalve species are vulnerable to the adverse impacts of environmental conditions and disease outbreaks. These outbreaks may affect all stages throughout the production process: larvae and post-larvae in hatcheries, as well as juvenile and adults, generally reared in an open environment. Massive mortalities may involve the complete loss of production stocks, with serious economic consequences. Increased hatchery production, livestock translocation, and species diversification contribute to increasing the occurrence and spread of infectious diseases. In recent years, disease outbreaks have significantly affected farmed oysters in Europe but also in other parts of the world (Paillard et al. 2004, FAO 2012).

\subsection{Mortality outbreaks in bivalve production associated with bacterial diseases}

Bacterial diseases, caused in particular by members of the genus Vibrio have been linked to mortalities in numerous bivalve species (Beaz-Hidalgo et al. 2010; Paillard et al. 2004). Bacillary necrosis, for example, initially described in larvae of Mercenaria mercenaria (Guillard 1959, Tubiash et al. 1965) touched by high mortality rates, also affects Crassostrea virginica, Ostrea edulis, Argopecten irradians and Teredo navalis. In addition to the species initially recognized as the causative agents of this necrosis: $V$. alginolyticus, $V$. tubiashii and $V$. 
anguillarum (Tubiash et al., 1970 and 1986), other pathogenic species have been recently identified. In the case of juveniles, four syndromes associated with bacterial detection have been reported to affect bivalves at this stage: Juvenile Oyster Disease (JOD) in C. virginica (Bricelj et al. 1992; Boettcher 1999, 2000), and, in the Pacific oyster, hinge ligament erosion disease (Dungan and Elston 1988; Dungan et al. 1989), chronic abscess syndrome (Elston et al. 1999) and spat mass mortality (Lacoste et al. 2001; Waechter et al. 2002).

Bacterial infections have however also been reported to result in mortalities in adult bivalves. Mass mortality outbreaks of clams (Venerupis philippinarum) leading to serious economic losses in France and Spain (Castro et al. 1990, 1992; Figueras et al. 1996; Paillard et al. 1989) have been associated with Brown Ring Disease (BRD), caused by Vibrio tapetis. Nocardiosishas also been linked with mass mortality episodes of adult Pacific oysters (Crassostrea gigas) in Japan (Takeuchi et al. 1955), California, Washington, and British Columbia (Elston 1993) and more recently the Netherlands (Eglesma et al. 2008). The etiological agent, Nocardia crassostreae, has also been shown to be pathogenic and lethal to flat oysters (Ostrea edulis) (Bower et al. 2005; Lauckner 1983).

Rickettsia-like organisms (RLOs) have been related to severe diseases and mortality outbreaks of marine bivalve molluscs including sea scallops (Placopecten magellanicus) (Gulka et al., 1983 and 1984) and (Pecten maximus) (Le Gall et al. 1988), giant clams (Hippopus hippopus and Tridacna gigas) (Norton et al. 1993a and 1993b), clams (Venerupis rhomboids) (Villalba et al. 1999), pearl oysters (Pinctada maximus and Pinctada fucata) (Wu and Pan 1999a; Wu and Pan 1999b; Wu and Pan 1999c); oysters (Crassostera ariakensis) (Wu and Pan 2000; Sun and Wu 2004) and hard clams Mercenaria mercenaria (Meyers 1981). Other affections caused by bacterial agents but not necessarily associated with mortality events were reviewed in a recent paper (Romalde and Barja 2010). 


\subsection{Mortality outbreaks in bivalve production caused by viral infections}

Viruses interpreted as members of various families (Papovaviridae, Togaviridae, Retroviridae, Reoviridae, Birnaviridae and Picornaviridae) have been described in bivalves (Farley et al. 1972; Farley 1976; Farley 1978, Meyers 1979; Oprandy et al. 1981; Rasmussen 1986; Bower 2001). Few studies have involved molecular identification and/or experimental in vivo trials confirming the affiliation and/or the pathogenicity of these agents (Renault and Novoa 2004). Infections by irido-like viruses were associated to massive mortality outbreaks of Crassostrea angulata between 1967 and 1973 (Comps et al. 1976; Comps and Bonami 1977; Comps and Duthoit 1979) and are interpreted as the main causes of the eradication of this species from European culture areas. The presence of herpes-like viruses has also been associated with disease outbreaks involving substantial mortalities in different bivalve mollusk species including Pacific oysters, flat oysters and European flat oysters (Farley et al. 1972; Hine et al. 1992; Comps and Cochennec 1993; Renault et al. 1994 a, b; Hine 1997, Hine and Thorne 1997).

Mass mortality outbreaks in association with the detection of a herpes-like virus were reported among larvae of hatchery-reared Pacific oyster for the first time in France during the summer of 1991 (Nicolas et al. 1992). At the same time, a herpes-like virus associated with larval mortality of hatchery reared Pacific oysters was reported in New Zealand (Hine et al. 1992). In the summer of 1992 and 1993, sporadic high mortalities (90-100\%) occurred among batches of Crassostrea gigas larvae in several French hatcheries. Reduction in feeding and swimming activity of larvae was observed three to four days after fecundation. Significant mortality occurred by day 6 , with $100 \%$ mortality by days 8-10 in most batches. Transmission electron microscopy examination showed the presence of herpes-like virus particles in infected larvae (Renault et al. 1994). The pathogenic capacity of the virus was demonstrated through experimental trials conducted on axenic larvae inoculated with 
suspensions obtained from infected larvae (Le Deuff et al. 1994). In New Zealand, mass mortalities $(60 \%$ to $100 \%)$ occurred in Pacific oyster larvae in 1991 in a hatchery in Auckland. Larvae affected by this mortality episode were examined by transmission electron microscopy and appeared to be infected with a herpes-like virus (Hine et al. 1992). In France, mass mortality outbreaks (80 to 90\%) among 3-7 month-old Pacific oysters were first reported in July of 1993 along the French Atlantic coast (Renault et al. 1994). The presence of herpes-like virus particles in the connective tissue of gills and mantle from moribund spat was demonstrated through transmission electron microscopy (Renault et al. 1994). Thanks to capsid purification and molecular identification a new viral species infecting Pacific oyster larvae and spat was defined. This virus was called ostreid herpesvirus 1 (OsHV1) (Le Deuff and Renault 1999; Davison et al. 2005)

A statistical correlation between OsHV-1 PCR positivity and mortality could be established in batches of oyster spat collected from French oyster rearing areas from 1992 to 1997 (Renault et al. 2000). Another epidemiological survey conducted from 1997 to 2006 by the French Repamo network (National Network for Surveillance and Monitoring of Mollusk Health) confirmed this association, with a peak in viral detection in May/June (Renault 2010; Garcia et al. 2011). In the United States, OsHV-1 was also detected by PCR in oyster spat affected by mass mortality episodes in California during the summer period (Friedman et al. 2005; Burge et al. 2006; Burge et al. 2007).

\section{OsHV-1 infection and massive mortality outbreaks affecting $C$. gigas spat}

\subsection{Geographical distribution}

Pacific oysters are produced worldwide: in Europe (France, Spain, United Kingdom, Ireland Channel islands, Norway), America (USA, Canada, Mexico, Argentina, Brazil, Chile, 
Ecuador, Peru, the Falkland Islands), Asia (Singapore, China, Taiwan, Japan, Republic of Korea, Hong Kong), Africa (Morocco, Tunisia, South Africa, Namibia, Senegal) and Oceania (Australia, New Zealand, and New Caledonia) (FAO 2014). Not all of these production areas are concerned by massive mortality outbreaks.

Herpesviruses infecting bivalve molluscs are virulent pathogens of both larval and seed oysters. Collectively, these viruses have been described as herpes-like viruses or oyster herpesvirus (OsHV). Mortalities of juvenile oysters associated with detection of herpesviral DNA have been reported in France, New Zealand, Mexico, Spain, and the USA (Burge et al. 2006; Friedman et al. 2005; Hine et al. 1992; Renault et al. 1994; Renault et al. 2000 ; Vazquez-Juarez et al. 2006; Elandaloussi et al. 2009).

More recently, mass mortality episodes of oyster spat were associated with the detection of a newly described OsHV-1 variant, called $\mu$ Var (Segarra et al. 2010). The latter has been reported in Europe: initially, in France (Martenot et al. 2010 and 2011, Segarra et al. 2010; Renault et al. 2012) and Ireland (Peeler et al. 2012) in 2008-2009, and subsequently in Great Britain, in particular in England, in the Kent area, in 2010 (EFSA 2010; Lynch et al. 2012). In Spain, OsHV-1 was detected for the first time by nested PCR (Renault et al. 2000b; Renault and Lipart 1998) in adult Pacific oysters collected in Catalonia in 2005 and originating from France (Elandaloussi et al. 2009; EFSA 2010). However more recent studies demonstrated the presence of a virus interpreted as the variant $\mu$ Var (Segarra et al. 2010) in samples collected from 2008 to 2010 during high mortality events in several locations (Roque et al. 2012). In Italy, simultaneous detection of the "reference type" and a virus interpreted as the variant $\mu$ Var in the absence of any pathological sign was achieved in juvenile oyster originating from France and collected the Marche region (Dundon et al.2011).

Outside of Europe, in the USA, OsHV-1 was detected by PCR in oyster spat affected by mass mortality episodes in California (Friedman et al. 2005; Burge et al. 2006; Burge et al. 2007). 
In Australia, a recent study was conducted to assess the spatial distribution of OsHV-1 associated with Crassostrea gigas mortality in Woolooware Bay (New South Wales, Australia) (Paul-Pont et al. 2013). Briefly, in October 2011 the authors placed healthy sentinel Pacific oysters in three different locations at three different tidal levels. OsHV-1 associated mortalities were closely monitored over 7 months. In two of the sites, the outbreaks started in November 2011 and mortalities affected $100 \%$ of the spat in less than one week. Only adults displayed differential mortality patterns in function of the rearing height. In the third southernmost location, massive mortality of spat oysters occurred three months later, in February and adult mortality was similar at all rearing heights. The disease remained active until April 2012. In France, the experimental demonstration of virus pathogenicity has not been achieved with all incriminated virus specimens. Moreover, detection of herpesviral DNA has also been occasionally achieved without any associated mortality. For instance, in Japan, PCR detection of OsHV-1 DNA was achieved in wild and cultivated Pacific oysters (Moss et al. 2007; Renault et al. 2011; and 2012, Shimahara et al. 2012). The amplified sequences were similar but not identical to the variant $\mu$ Var. However, the pathogenicity of the detected specimens has not been demonstrated (Shimahara et al. 2012). Sequence variation raises the issue of the genetic diversity of OsHV-1, which will be analysed in the following paragraph

\subsection{Virus diversity}

OsHV-1 is a DNA virus that was recently classified in the Malacoherpesviridae family from the Herpesvirales order (Davison et al. 2009). This virus has been associated with mortality outbreaks in the Pacific cupped oyster, Crassostrea gigas, since 1991. With the development of molecular tools, a variant, named OsHV-1var (Arzul et al. 2001a) was described. This "variant" presented several modifications in the "C region", which encompasses ORFs 114, 4 and 5, including a $2.8 \mathrm{kpb}$ deletion (Arzul et al. 2001a) (Figure 3). It was associated with 
mortality episodes affecting Ruditapes phillipinarum (Arzul et al., 2001a), C. gigas and Pecten maximus (Arzul et al., 2001b) in French hatcheries. Despite the above mentioned differences, the "reference type" and the variant var are considered representatives of a single viral species (Arzul et al., 2001a).

Since 2008, a significant increase in the occurrence, intensity and geographic distribution of these outbreaks has been reported. This augmentation has been related to the detection of a particular OsHV-1 variant called $\mu$ Var. This variant was described on the basis of specific polymorphisms in ORF4 (GenBank accession no. HQ842610-1) and ORFs 42-43 (Segarra et al. 2010). In particular, ORF4 of the variant $\mu$ Var is affected by a deletion at a microsatellite site (12 consecutive nucleotides followed by a deletion of one adenine) that does not exist in the « reference » genome of OsHV-1 (GenBank accession no.AY509253) (Davison et al. 2005; Segarra et al. 2010).

The infectivity and strong pathogenicity of the variant $\mu$ Var was shown by injection of oysters with affected spat homogenates (Schikorski et al. 2011a and b). Although $\mu$ Var specimens have been detected in samples collected after 2008, a PCR assay targeting ORF4 yielded positive results in samples collected in France in 2004 and 2005 suggesting the presence of $\mu$ Var or related variants prior to 2008 (Martenot et al. 2012). A summary of the detection of OsHV-1 and its variants in association with mortality events is provided in Figure 1.

Because the size of the deletion at the microsatellite site appears to be variable, additional variants have been defined based on this feature, such as OsHV-1 " $\mu$ Var $\Delta 9$ " and " $\mu$ Var $\Delta 15$ " (Martenot et al. 2011 and 2012). The variant " $\mu$ Var $\Delta 9$ " has been detected in moribund as well as in apparently healthy oysters (spat, juveniles and adults) collected during mortality outbreaks in France (2009 and 2010). The variant " $\mu$ Var $\Delta 15$ " was found in samples collected in France in 2010. It is currently unknown whereas these variants differ from the variant $\mu$ Var 
in terms of virulence. The term $\mu$ Var should only be used for specimens displaying all the mutations described by Segarra et al. (2010) in ORF4 and ORFs 42-43.

The variations occurring at ORF4 have raised interest in the characterization of the genetic variability among OsHV-1 specimens. Recent studies have shown that the analysis of the sequences of three particular regions (ORF4, ORFs35-36-37-38 and ORFs42-43), both independently and as concatemerized units, make it possible to define different sub-groups within known «genotypes» (Renault et al. 2012). In this study, the described methodology was applied to the analysis of a set of 72 samples collected between 1993 and 2010 mainly in France but also in Ireland, USA, China, Japan and New Zealand. Briefly, results from French samples are as follows: samples collected between 1993 and 2003 were mostly (88\%) identical to the reference type, one third (32\%) of all samples collected between 2005 and 2008 displayed differences as they did not yield amplicons with the Del 36-37F2/Del 36-37R primer set and $47 \%$ samples collected in 2008 were identical to OsHV-1 $\mu$ Var. In addition, the reported data suggest that OsHV-1 $\mu$ Var and the reference type share a common ancestor the former is not directly derived from the latter. Finally, ORF4 appeared as the most polymorphic genome area distinguishing several genogroups.

Since the publication of these results, samples from a wide range of locations have been screened using the same approach. The generated data tend to indicate that the genetic diversity of the virus may be larger than anticipated and that the sole presence of the characteristic deletion at ORF4 may not be sufficient to classify the specimen as the variant $\mu$ Var (Barbosa-Solomieu et al., pers. comm.) as previously reported by Segarra et al. (2010). Further analysis of the genetic diversity of OsHV-1 may provide insights about the phylogenic relationships between specimens collected in different areas and the spread of the virus

\subsection{Virus infection and environmental factors}




\subsubsection{Seawater temperature}

Although OsHV-1 infections related to mortality events including the 2008-2012 outbreaks across Europe have mainly occurred in spring/summer months suggesting a key role of the water temperature, few studies have targeted the role of temperature on viral infection under experimental conditions (Le Deuff et al. 1994; Le Deuff et al. 1996; Sauvage et al. 2009). Le Deuff et al. (1996) showed the existence of a relationship between high water temperatures and both the production of viral particles and the mortality of Pacific oyster larvae. A study by Sauvage et al. (2009) suggests that, in laboratory conditions, a mean seawater temperature of $23.8^{\circ} \mathrm{C}$ and its rapid increase $\left(2.3^{\circ} \mathrm{C}\right.$ over 2 days $)$ are favorable to the onset of an OsHV-1 outbreak among $C$. gigas spat. More recently, experimental assays demonstrated that successful infections of Pacific oyster spat by OsHV-1 can be achieved at water temperatures between $20-22^{\circ} \mathrm{C}$ (Schikorski et al. 2011a and b).

Several studies have identified seawater temperature as a key factor in terms of OsHV-1 detection during mortality outbreaks in the field. An OsHV-1 survey carried out in France from 1997 to 2006 showed that virus detection followed a gradient of increasing seawater temperatures along French coasts (Garcia et al. 2011). These authors also reported that the onset of mortality events was usually preceded by a rapid increase of mean seawater day temperatures In the USA, a similar data have been generated as seawater temperatures of $24-25^{\circ} \mathrm{C}$ have been recorded prior disease outbreaks (Burge et al. 2006; Burge et al. 2007). A study carried out in the Marennes-Oleron area (Charente Maritime, France) (Renault et al. 2014) also suggested that a rapid increase of seawater temperature beyond a particular threshold is a crucial trigger for mortality outbreaks related to OsHV-1 infection. Clegg et al. (2014) studied $C$. gigas mortality events that occurred in Ireland during the summer of 2011 and indicated an increase of mortalities along with seawater temperature until a peak was reached. This is similar to the observations made by Pernet et al (2014) in the Thau lagoon in France. 
As a conclusion, high seawater temperatures appear as a main factor inducing OsHV-1 infection. Comparable observations have been made for herpesviruses infecting vertebrates: for example, temperatures between $18^{\circ} \mathrm{C}$ and $28^{\circ} \mathrm{C}$ have been shown to favor the onset and the severity of Koi herpesvirus infection in fish (Gilad et al. 2003; Hara et al. 2006; Pokorova et al. 2005; Saint-Hilaire et al. 2005; Sano et al. 2004; Yuasa et al. 2008). However, it remains difficult to define a precise temperature threshold leading to enhanced OsHV-1 expression or mortality. The temperature threshold was variable following the rearing site, ranging from $22^{\circ} \mathrm{C}$ to $25^{\circ} \mathrm{C}$ on the west coast of the USA (Burge et al. 2006; Burge et al. 2007) and from $16^{\circ} \mathrm{C}$ to $24^{\circ} \mathrm{C}$ in France (Pernet et al. 2014; Petton et al. 2013; Samain and McCombie 2008, Soletchnik et al. 1999). Moreover, Renault et al. (2014) suggested that viral contamination can occur among oysters in absence of mass mortality and when the water temperature is below $16^{\circ} \mathrm{C}$.

\subsubsection{Other environmental parameters}

Other parameters known to influence mechanism of disease transmission in aquatic environments (hydro-dynamics, physical disturbances, host density/distribution, and variations of environmental parameters) have been suggested as factors influencing OsHV-1 infection (Barbosa-Solomieu et al. 2005; Burge et al. 2007; Friedman et al. 2005; Garcia et al. 2011, Paul-Pont et al. 2013; Renault et al. 1994a and b). Paul-Pont et al. (2013) assessed the spatial distribution of OsHV-1-associated mortality in Woolooware Bay (New South Wales, Australia) using healthy sentinel Pacific oysters and showed that mortality could depend on oyster position in the seawater column. They also suggested that OsHV-1 may be carried through water by particles, possibly plankton. Pernet et al. (2014) carried out a spatial and temporal study of a mass mortality outbreak related to OsHV-1 infection. They investigated oyster spat mortality in relation to energetic reserves and food quality in animals deployed at several locations in the Thau lagoon on the Mediterranean coast (France). These 
authors showed that the dynamics of spat mortality was significantly correlated to differences in energetic condition, partly driven by variation in food quality and relative contribution of diatoms to the diet of oysters. Future studies should aim at developing improved methods to assess oyster mortality and follow stocks over time to better determine the influence of environmental factors on mortality.

\subsection{Virus infection and host factors}

\subsubsection{Susceptible host species}

Pacific oyster, C. gigas, Portuguese oyster, C. angulata, suminoe oyster, C. ariakensis, European flat oyster, Ostrea edulis, Manila clam, Venerupis philippinarum, carpet shell clam, $V$. decussatus, scallops, P. maximus are naturally infected (Arzul et al. 2001; Renault et al. 2001). Interspecies transmission from infected axenic larvae of $C$. gigas to axenic larvae of $C$. ariakensis and $O$. edulis was demonstrated under experimental conditions (Arzul et al. 2001b). An OsHV-1 suspension prepared from $V$. philippinarum infected larvae was able to infect $C$. gigas larvae, and a virus suspension from $C$. gigas was shown to infect $C$. angulata larvae (Arzul et al. 2001b).

OsHV-1 ( $\mu$ Var) DNA has been recently detected in France in blue mussel, Mytilus edulis, and in Donax trunculus by PCR and PCR product sequencing (Renault et al., pers. comm.). However, it's no clear if those bivalves are disease susceptible or act as vectors.

\subsubsection{Persistent infection}

Apparently healthy oysters, including adults, may be PCR-positive for OsHV-1 DNA detection (Arzul et al. 2002; Moss et al. 2007, Sauvage et al. 2009, Segarra et al. 2014). Pépin et al. (2008) showed that DNA copy numbers $\mathrm{mg}^{-1}$ were high (up to $10^{7}$ ) in oysters from populations with abnormal mortalities and low (lowest number detected $10^{1}$ ) in populations with no abnormal mortality. 
Mortality related to OsHV-1 detection is significantly lower or absent in adult oysters compared with other age groups (Arzul et al. 2002; Peeler et al. 2012). However, the virus (DNA, protein or particles) has been detected in tissues of adult oysters, including gonads (Arzul et al. 2002, Lipart and Renault 2002). These observations suggest that adults may be a source of infection for the most susceptible age groups, larvae or spat, particularly if the parent animals are under stress, e.g. from high temperature (Le Deuff et al. 1996). However, it is not certain whether true vertical transmission (transmission within the gametes) occurs or whether transmission is strictly horizontal (Barbosa-Solomieu et al. 2005).

\subsubsection{Susceptibility to the viral infection and viral immune response}

Several studies support the hypothesis of a genetic basis underlying resistance to OsHV-1 infection in the Pacific oyster, C. gigas (Dégremont 2011, Sauvage et al. 2009, Segarra et al. 2014). In addition, differences in terms of susceptibility to the viral infection appeared associated with differences in host gene expression (Segarra et al. 2014). Sauvage et al. (2009) investigated the disease susceptibility of different families of Pacific oyster studying 3 groups of animals from 3 families in laboratory conditions. Significant differences in terms of mortality rates and OsHV-1 DNA detection were reported between oysters belonging to the different families. All animals were maintained in a single raceway and equally exposed to the risk of infection. Therefore, the obtained results strongly suggest the existence of differential susceptibility towards viral infection among oysters (Sauvage et al. 2009). Conversely, Segarra et al. (2014) reported a divergent response of Pacific oyster families in terms of mortality during an experimental OsHV-1 ( $\mu$ Var) infection. They also suggested that oysters are genetically diverse in terms of susceptibility to OsHV-1 infection. An initial phase of active virus replication characterized by an increase in the detected amounts of viral DNA and RNA, was followed by a rapid decrease in viral DNA and RNA detection. These results suggest that the 
host immune defence was activated and that some oysters were able to circumvent OsHV-1 infection (Segarra et al. 2014).

Renault et al. (2011) are the first authors to report data on genes related to antiviral immunity in the Pacific oyster. These authors studied virus-induced genes in Pacific oyster haemocytes challenged by OsHV-1 through Suppressive Subtraction Hybridisation (SSH). Different genes already known as immune-related genes were thus identified. Investigation of oyster gene expression by real-time RT PCR showed a significant increase of MyD88 gene transcripts in experimentally infected oysters. Segarra et al. (2014) reported similar results and suggested that the over expression of MyD88 could be interpreted more as a marker of the infectious process and viral replication than a marker of an effective antiviral response. Recently, Green et al. (2014) carried out a study to determine how Pacific oyster ontogeny interacts with water temperature to influence the antiviral response against OsHV-1 infection. For this purpose, they measured the effect of temperature $\left(12\right.$ vs $\left.22^{\circ} \mathrm{C}\right)$ on oyster immune response after poly I:C injection. They reported that the expression of genes related to immunity was influenced by temperature and oyster age (Green et al., 2014).

\subsubsection{Stress and viral infection}

Stress conditions (handling, transport, crowding, modification of feeding, pesticides) have also been suggested as factors involved in the development of viral disease (Renault et al. 2010; Barbosa-Solomieu et al. 2005; Burge et al. 2007; Friedman et al. 2005; Garcia et al. 2011, Normand et al. 2014). Moreau et al. (2015) reported that exposure of Pacific oysters to a mixture of 14 pesticides was related to increased mortality rates that could be interpreted as an increased susceptibility to OsHV-1 infection.

\subsection{Co-detection of OsHV-1 and vibrios}


The co-detection of OsHV-1 and different Vibrio species including $V$. splendidus and $V$. aestuarianus has been reported during mass mortality events affecting Pacific oysters in Europe since 2008 (Efsa 2010). Saulnier et al. (2010) reported results obtained during a 4-year bacteriological survey (2003-2007) of French Pacific oysters. Bacteria identified as belonging to $V$. Splendidus clade and $V$. aestuarianus species were mainly detected in samples collected during mortality events. A large number of $V$. harveyi related strains were reported in association to 2007 oyster mortality outbreaks (Saulnier et al. 2010). OsHV-1 (reference type) DNA was also detected during this period in France in association with mortality events affecting $\mathrm{Pa}$ cific oysters (Garcia et al. 2011). Keeling et al. (2014) conducted a field study during the 2010-11 mortality outbreak in New Zealand and detected OsHV-1 through a PCR approach. They also identified several Vibrio species: V. splendidus, V. aestuarianus and V. alginolyticus. These bacterial species have previously been associated with mortality in marine bivalves (Le Roux et al. 2002; Gómez-León et al. 2005; Saulnier et al. 2010). Identification of key Vibrio species in addition to OsHV-1 suggests that complex interactions may occur between different pathogens in the marine environment

\section{Infection with Vibrio aestuarianus and massive mortality outbreaks affecting adult Pacific oysters}

\subsection{Geographical distribution}

Vibrio aestuarianus was initially isolated and described by Tison \& Seidler (1983) from seawater, oysters, clams and crabs from the Oregon and Washington coasts (USA), in absence of animal mortality. Epidemiological studies on C. gigas juvenile and adult mortality outbreaks reported along the French coast have revealed the presence of $V$. aestuarianus in moribund animals and their environment since 2001 (Garnier et al. 2007; Saulnier et al. 2010 
Azandégbé et al. 2010). These French isolates, pathogenic for Crassostrea gigas, were included in a newly defined subspecies: $V$. aestuarianus subsp. francensis in opposition with the American type strain: V. aestuarianus subsp. aestuarianus (Garnier et al. 2008) (Figure 2). Since 2012, the frequency at which $V$. aestuarianus has been reported during oyster mortality outbreaks in France has increased (Garcia et al. 2014), suggesting a (re)emergence of this pathogen. However, by combining genome analyses and experimental infections on a large collection of strains, the authors did not observe any correlation between lethal dose, genotype and isolation date, suggesting that the emergence of a new virulent clonal strain is unlikely (Goudenège et al. 2014). Therefore, the recent outbreaks in France (Garcia et al. 2014; Goudenège et al. 2014) may be at least partially explained by a number of physiological disorders of oysters leading to an increased susceptibility to $V$. aestuarianus, and/or environmental factors (abiotic and biotic) favouring the multiplication, persistence or virulence of the bacteria.

Additionally, since 2001, V. aestuarianus has been detected in different sites in Europe in the absence of noticeable mollusc mortalities. Few environmental studies have reported its presence in coastal areas: Baltic sea (Eiler 2006), Spain (Montes et al. 2003), Hong Kong (Wang et al. 2006). More recently, an intensive field survey conducted as part of the European project Bivalife allowed its detection and isolation within the context of spat mortality in Italy (Goro lagoon) (Vezzulli et al. 2014, Domenghetti et al. 2014). However, the virus OsHV-1 was suspected to be implicated in those mortality events. Viral DNA was detected in high amounts in moribund animals and the $V$. aestuarianus strains that had been isolated were classified as non-virulent following experimental infections (Goudenège et al. 2014). Three $V$. aestuarianus strains were also isolated in absence of mortality in Spain (Galicia), from oyster, plankton and mussels (Romero et al. 2014). The classification of those isolates into either of the two subspecies is however still unknown. 


\subsection{Bacterial diversity}

An initial study comparing $11 \mathrm{~V}$. aestuarianus isolates from moribund oyster hemolymph revealed a very low diversity on the basis of $16 \mathrm{~S}$ rRNA, gyrB and toxR genes, indicating a high degree of homogeneity (Garnier et al. 2008). Similarly, genomic analyses of $14 \mathrm{~V}$. aestuarianus isolates revealed the cohesive genotypic structure of $V$. aestuarianus with relatively little diversity among genomes (Goudenège et al. 2014). This study confirmed that $V$. aestuarianus species grouped with two species containing fish pathogens, $V$. ordalii and $V$. anguillarum, into the Anguillarum clade (Goudenège et al. 2014), as previously suggested (Sawabe et al. 2013). Moreover, genome analyses revealed the existence of two virulent lineages with very low intra-clade and inter-clade diversity and containing each a majority of virulent strains (Goudenège et al. 2014). The question of the ecological signification of those groups has now to be addressed.

These studies are nevertheless mainly based on isolates collected during mortality events. The few non virulent strains that have been studied (isolated from zooplankton in Italy, cockles in France and healthy oysters in Spain) were found to be more diverse (Goudenège et al. 2014) suggesting that the diversity of environmental isolates is higher than the one of strains capable of causing oyster disease.

\subsection{Bacterial infection and environmental factors (temperature and salinity)}

Mortality reports analysed by the French surveillance network (Repamo) revealed that individuals affected by $V$. aestuarianus were preferentially detected in summer (Garcia et al. 2014), suggesting a link between pathogenesis with temperature, even if mortality were noticed all year-long. A first study revealed that juveniles and adult oysters are more sensitive to $V$. aestuarianus infection (Dégremont et al. 2014). However, the evolution of oyster 
sensitivity to $V$. aestuarianus infection with age and/or size is currently unknown.

Temperature and salinity can influence virulence expression (i.e. pathogenesis) but also bacterial persistence and growth in the environment (Vezzulli 2013).

\subsubsection{Effect of temperature and salinity on the virulence of $V$. aestuarianus}

In experimental conditions, after intramuscular injection of cultured $V$. aestuarianus, mortality can be induced from $10^{\circ} \mathrm{C}$ to $32^{\circ} \mathrm{C}$ and extended from 24 hours $\left(32^{\circ} \mathrm{C}\right)$ to 25 days $\left(10^{\circ} \mathrm{C}\right)$ (Travers et al,. pers. comm.; Dégremont et al. 2014). Field studies indicated that temperatures between 19 and $23^{\circ} \mathrm{C}$ seem to favour bacterial growth and infection (Garnier et al. 2007). However, mortalities were also reported at lower temperatures (Dégremont et al. 2014).

Even if the demonstration of a direct impact of temperature and/or salinity on the expression of virulence genes is not available yet, those parameters surely have an indirect impact on bacterial virulence. One known virulence factor, the metalloprotease Vam (Labreuche et al. 2010) is regulated by quorum sensing mechanisms (De Decker et al. 2013), themselves controlled by bacterial growth (Waters and Bassler 2005). Under laboratory conditions, optimal conditions for $V$. aestuarianus growth ranged from $20^{\circ} \mathrm{C}$ to $25^{\circ} \mathrm{C}$ (Vezzulli et al. 2014) and the optimal salinity was around $20 \%$, with a generation time around $60 \mathrm{~min}$ at $20^{\circ} \mathrm{C}$.

However, as demonstrated for mussels (Asplund et al. 2014), the impact of environmental factors can be mainly reflected on the host-pathogen interaction rather than the pathogen or the host taken individually.

\subsubsection{Effect of temperature ad salinity on the persistence and growth of $V$. aestuarianus}

Little information is available on the ecology of virulent strains of $V$. aestuarianus in the environment and the impact of environmental conditions on the persistence and niche colonization of the bacteria. 
The first study on its ecology demonstrated that, regardless of salinity and temperature (test conditions ranged from 5 to $25^{\circ} \mathrm{C}$ and 20 to 35\%o), V. aestuarianus can only persist a few days in seawater in the absence of nutrients (Vezzulli et al. 2014). So, despite the impact of temperature and salinity on bacterial growth (Garnier et al. 2008), V. aestuarianus presents a low persistence potential in seawater in the absence of nutrients or potential planktonic partner. This is in agreement with ecological studies that only sporadically detected its presence in seawater, without any correlation with temperature and salinity (Vezzulli et al. 2014, Domeneghetti et al. 2014).

Temperature and salinity can also influence the mode of life of the bacteria that can enter into a VBNC (Viable But Non Culturable) state to persist during winter (Azandégbé 2010). This author reported that small bacteria $(<0.2 \mu \mathrm{m})$ with an intact membrane structure can be observed in seawater after a long term incubation at $5^{\circ} \mathrm{C}$ and $20 \%$. Similarly, in sediment, despite low temperatures $\left(5^{\circ} \mathrm{C}\right)$, around $30 \%$ of the bacteria added in the mesocosm remained viable throughout the entire duration of the experiment and never dropped below $10^{4}$ cells. $\mathrm{ml}^{-}$ ${ }^{1}$ (Vezzulli et al. 2014).

In conclusion, in addition to having an impact on the pathogenesis of $V$. aestuarianus, environmental conditions appear to drive bacterial status, persistence and, potentially, niches. Conditions for bacterial persistence in environment and virulence expression are well described but we still need to define conditions where initial contamination / infection do not occur.

\subsection{Bacterial infection and physiological factors}

In co-infection experiments mixing $V$. splendidus LGP32 and V. aestuarianus 02/041 carried out at different dates on similar C. gigas batches, De Decker et al. (2011) proposed a link between reproductive status and survival performances of the oysters. They suggested that 
reproductive effort leads to a state of physiological weakness resulting in an increased Vibrio susceptibility during summer. During reproductive season, oyster hemocytes were reported to display lower phagocytic activity and adhesion capacity. These immune functions are known to be targeted by the bacteria (Labreuche et al. 2006a-b), and particularly the secreted metalloprotease Vam (Labreuche et al. 2010).

The production of divergent Pacific oyster lines for reproductive allocation and/or the comparison of lineages with contrasted survival capacities could be a way to demonstrate correlations between reproduction and susceptibility to Vibrios.

\section{Concluding remarks}

Although infectious diseases appear as the main causes of mass mortality events in bivalve mollusks, as illustrated by the case of the Pacific oysters, environmental factors (water temperature, salinity, presence of pollutants, trophic conditions) may have an impact on the host and the pathogen themselves but also on the host/pathogen relationship.

Host factors, some of which are genetically driven also play a crucial role, as they have an influence on host susceptibility towards infection by viral and bacterial agents. In the presence of pathogens, the combination of a few or all of these parameters may result in mortality outbreaks in locations and under conditions that are seemingly unrelated. Further experimental trials mimicking particular field conditions may allow to better understanding host-pathogen interactions and the variability of the outcome of viral, bacterial and combined infections. 


\section{References}

Azandegbe, A., Garnier, M., Andrieux-Loyer, F., Kerouel, R., Philippon, X. \& Nicolas, J. L. 2010. Occurrence and seasonality of Vibrio aestuarianus in sediment and Crassostrea gigas haemolymph at two oyster farms in France. Dis. Aquat. Org. 91, 213-221.

Arzul, I., Renault, T., Lipart, C., Davison, A.J., 2001a. Evidence for interspecies transmission of oyster herpesvirus in marine bivalves. J. Gen. Virol. 82, 865-870.

Arzul, I., Nicolas, J.-L., Davison, A.J., Renault, T., 2001b. French scallops: a new host for Ostreid herpesvirus-1. Virol. 290, 342-349.

Arzul, I., Renault, T., Thébault, A., Gérard, A. 2002. Detection of oyster herpesvirus DNA and proteins in asymptomatic Crassostrea gigas adults. Virus Res. 84, 151-160.

Beaz-Hidalgo, R., Balboa, S, Romalde, J.L., Figueras, M.J. 2010. Diversity and pathogenicity of Vibrio species in cultured bivalve molluscs. Environ. Microbiol. Rep. 2, 34-43.

Barbosa-Solomieu, V., Dégremont, L., Vazquez-Juarez, R., Ascencio-Valle, F., Boudry, P., Renault, T. 2005. Ostreid Herpesvirus 1 detection among three successive generations of Pacific oysters (Crassostrea gigas). Virus Res. 107, 47-56.

Bower, S.M., Goh, B., Meyer. G.R., Carnegie, R.B., Gee, A. 2005. Epizootiology and detection of nocardiosis in oysters. In: Walker, P., Lester, R.G., Bondad-Reantaso, M.G. (Eds.), 5th Symp Diseases in Asian Aquaculture, November 24-28, 2002, Surfer's Paradise, Queensland. Fish Health Section, Asian Fisheries Society, Manila, pp. 249-262.

Bower, S.M. 2001. Synopsis of infectious diseases and parasites of commercially exploited shellfish: Assorted viruses detected in oysters and of unknown significance. ULR: http://www-sci.pac.dfo-mpo.gc.ca/shelldis/assortvirusoy_e.htm.

Bricelj, V.M., Ford, S.E., Borrero, F.J., Perkins, F.O., Rivara, G., Hillman, R.E., Elston, R.A., Chang, J. 1992. Unexplained mortalities of hatchery-reared, juvenile oysters, Crassostrea virginica (Gmelin). J. Shellfish Res. 11, 331-347. 
Boettcher, K.J., Barber, B.J., Singer, J.T. 1999. Use of antibacterial agents to elucidate the etiology of Juvenile Oyster Disease (JOD) in Crassostrea virginica and numerical dominance of an a-proteobacterium in JOD-affected animals. Appl. Environ. Microbiol. 65, 2534-2539. Boettcher, K.J., Barber, B.J., Singer, J.T., 2000, Additional evidence that juvenile oyster disease is caused by a member of the roseobacter group and colonization of nonaffected animals by Stappia stellulata-like strains. Appl. Environ. Microbiol. 66, 3924-3930

Burge, C.A., Griffin, F.J., Friedman, C.S. 2006. Mortality and herpesvirus infections of the Pacific oyster Crassostrea gigas in Tomales Bay, California, USA. Dis. Aquat. Org. 72, 3143.

Burge, C., Judah, L.R., Conquest, L.L., Griffin, F.J., Cheney, D.P., Suhrbier, A., Vadopalas, B., Olin, P.G., Renault, T., Friedman, C.S. 2007. Summer seed mortality of the Pacific oyster, Crassostrea gigas Thunberg grown in Tomales Bay, California, USA: the influence of oyster stock, planting time, pathogens, and environmental stressors. J. Shellfish Res. 26:163-172.

Castro, D., Moriñigo, M. A., Martínez, E., Cornax, E., and Borrego, J. J. 1990. Microflora associated with "brown ring" from clams (Tapes semidecussatus) cultured in southwestern Spain, p 56. In "Abstracts 4th Int. Coll. Pathol. Mar. Aquac" (A. Figueras, Ed.), September 1990, Vigo, Spain.

Castro, D., Martínez-Manzanares, E., Luque, A., Fouz, B., Moriñigo, M. A., Borrego, J. J., and Toranzo, A. E. 1992. Characterization of strains related to brown ring disease outbreaks in southwestern Spain. Dis. Aquat. Org. 14, 229-236.

Cheslett D. 2014. Vibrio aestuarianus in Ireland. Annual Meeting of the National Reference Laboratories for Mollusc Diseases. Nantes, 25-26 March 2014.

Clegg, T.A., Morrissey, T., Geoghegan, F., Wayne Martin, S., Lyons, K., Ashe, S., More, S.J. 2014. Risk factors associated with increased mortality of farmed Pacific oysters in Ireland during 2011. Preventive Vet. Med. 113, 257-267. 
Comps, M., Bonami, J.R., Vago, C., Campillo, A. 1976. Une virose de l'huître portugaise

(Crassostrea angulata Lmk). C. R. Hebd. Séanc. Acad. Sci. D 282, 1991-1993.

Comps, M., Bonami, J.R. 1977. Infection virale associée à des mortalités chez l'huître Crassostrea angulata Th. C. R. Acad. Sci. D 285, 1139-1140.

Comps, M., Duthoit, J.L., 1979, Infections virales chez les huîtres Crassostrea angulata (Lmk) et C. gigas (Th.). Haliotis 8 (1977), 301-308.

Comps, M., Cochennec, N. 1993. A herpes-like virus from the European oyster Ostrea edulis L. J. Invertebr. Pathol. 62: 201-203.

Davison, A.J., Trus, B.L., Cheng, N., Steven, A.C., Watson, M.S., Cunningham, C., Le Deuff, R.M. and Renault, T. 2005. A novel class of herpesvirus with bivalve hosts. J. Gen. Virol. 86, 41-53.

Davison, A.J., Eberle, R., Ehlers, B., Hayward, G.S., McGeoch, D.J., Minson, A.C., Pellett, P.E., Roizman, B., Studdert, M.J. and Thiry, E. 2009. The order Herpesvirales, Arch. Virol. $154,1,171-177$.

De Decker, S. and Saulnier, D. 2011. Vibriosis induced by experimental cohabitation in Crassostrea gigas: Evidence of early infection and down-expression of immune-related genes. Fish Shellfish Immunol.30, 691-699.

De Decker, S., Normand, J., Saulnier, D., Pernet, F., Castagnet, S. \& Boudry, P. 2011. Responses of diploid and triploid Pacific oysters Crassostrea gigas to Vibrio infection in relation to their reproductive status. J. Invertebr. Pathol. 106, 179-191.

Dégremont, L. 2011. Evidence of herpesvirus (OsHV-1) resistance in juvenile Crassostrea gigas selected for high resistance to the summer mortality phenomenon. Aquaculture. 317, (1-4), 94-98. 
Dégremont, L., Azéma, P., Travers, M. A. 2014. Spat and adult mortality related to Vibrio aestuarianus in Crassostrea gigas in France. National Shellfish Association Meeting. Jacksonville, Florida, USA.

Domeneghetti, S., Varotto, L., Civettini, M., Rosani, U., Stauder, M., Pretto, T., Pezzati, E., Arcangeli, G., Turolla, E., Pallavicini, A. \& Venier, P. 2014. Mortality occurrence and pathogen detection in Crassostrea gigas and Mytilus galloprovincialis close-growing in shallow waters (Goro lagoon, Italy). Fish Shellfish Immunol.

Dundon WG, Arzul I, Omnes E, Robert M, Magnabosco C, Zambon M, Gennari L, Toffan A, Terregino C, Capua I, Arcangeli G. 2011. Detection of Type 1 Ostreid Herpes variant (OsHV$1 \mu$ var) with no associated mortality in French-origin Pacific cupped oyster Crassostrea gigas farmed in Italy. Aquacult. 314 (1-4):49-52.

Dungan, C.F., Elston, R.A. 1988. Histopathological and ultrastructural characteristics of bacterial destruction of hinge ligaments of cultured juvenile Pacific oysters, Crassostrea gigas. Aquaculture. 72, 1-14.

Dungan, C.F., Elston, R.A., Schiewe, M.H. 1989. Evidence and colonization and destruction of hinge ligaments in cultured juvenile oysters (Crassostrea gigas) by cytophaga-like bacteria. Appl. Environ. Microbiol. 55, 1128-1135.

Efsa. 2010. Scientific opinion on the increased mortality events in Pacific oysters, Crassostrea gigas, EFSA J. 8,1-59.

Eglesma, M.Y., Roozenburg, I., Joly, J.P., 2008. First isolation of Nocardia crassostreae from Pacific oyster Crassostrea gigas in Europe. Dis. Aquat. Org. 80, 229-234.

Eiler, A., Johansson, M., Bertilsson, S. 2006. Environmental influences on Vibrio populations in northern temperate and boreal coastal waters (Baltic and Skagerrak Seas). Appl. Environ. Microbiol. 72, 6004-6011. 
Elandaloussi L, Carrasco N, Andree K, Furones D, Roque A, 2009. Esdeveniments de mortalitat de lostró del Pacific (Crassostrea gigas) en el delta del Ebre. Estudi de cas. Proceedings of the II Simposi d'aqüicultura de Catalunya. Sant Carles de la Rapita, Spain Elston, R.A., 1993. Infectious diseases of the Pacific oyster Crassostrea gigas. Annu.

Rev. Fish Dis. 3, 259-276.

Elston, R.A., Frelier, P., Cheney, D., 1999, Extrapallial abscesses associated with chronic bacterial infections in the intensively cultured juvenile Pacific oyster Crassostrea gigas. Dis. Aquat. Org. 37, 115-120.

FAO 2014. Food and Agriculture Organization of the United Nations, Species Fact Sheet,

\section{Crassostrea gigas}

FAO STAT 2012

Farley, C.A. 1976. Ultrastructural observations on epizootic neoplasia and lytic virus infection in bivalve mollusks. Prog. Exp. Tumor Res. 20, 283-294.

Farley, C.A., 1978. Viruses and virus-like lesions in marine molluscs. Mar. Fish. Rev. 40, 1820.

Farley, C.A., Banfield, W.G., Kasnic, J.R.G., Foster, W.S. 1972. Oyster herpes-type virus. Science, Wash. DC 178, 759-760.

Figueras, A., Robledo, J. A. F., and Novoa, B. 1996. Brown ring disease and parasites in clams (Ruditapes decussatus and R. phlippinarum) from Spain and Portugal. J. Shellfish Res. $15,363-368$.

Friedman, C.S., Estes, R.M., Stokes, N.A., Burge, C.A., Hargove, J.S., Barber, B.J., Elston R.A., Burreson, E.M., Reece, K.S. 2005. Herpes virus in juvenile Pacific oysters Crassostrea gigas from Tomales bay, California, coincides with summer mortality episodes. Dis. Aquat. Org. 63:33-41.

Garcia C, Arzul I, Chollet B, Robert M, Omnes E, Ferrand S, Faury N, Tourbiez D, Haffner P, 
Miossec L, Joly JP and François C, 2014. Vibrio aestuarianus and Pacific oysters, Crassostrea gigas mortality in France: a new chapter in their relation. Proceedings of the National Shellfish Association, Jacksonville, Florida, USA.

Garcia, C., Thébault, A., Dégremont, L., Arzul, I., Miossec, L., Robert, M., Chollet, B., François, C., Joly, J.P., Ferrand, S., Kerdudou, N., Renault, T. 2011. OsHV-1 detection and relationship with C. gigas spat mortality in France between 1998 and 2006. Vet. Res. 42, 7384.

Garnier, M., Labreuche, Y., Garcia, C., Robert, A. \& Nicolas, J. L. 2007. Evidence for the involvement of pathogenic bacteria in summer mortalities of the Pacific oyster Crassostrea gigas. Microbial Ecol. 53, 187-196.

Garnier, M., Labreuche, Y. \& Nicolas, J.-L. 2008. Molecular and phenotypic characterization of Vibrio aestuarianus subsp francensis subsp nov., a pathogen of the oyster Crassostrea gigas. Systematic Appl. Microbiol. 31, 358-365.

Gilad, O., Yun, S., Adkison, M.A., Way, K., Willits, N.H., Bercovier, H., Hedrick, R.P. 2003. Molecular comparison of isolates of an emerging fish pathogen, koi herpesvirus, and the effect of water temperature on mortality of experimentally infected koi. J. Gen. Virol. 84, 2661-2668.

Gómez-León, J., Villamil, L., Lemos, M.L., Novoa, B., Figueras, A. 2005. Isolation of Vibrio alginolyitcus and Vibrio splendidus from aquacultured carpet shell clam (Ruditapes decussatus) larvae associated with mass mortalities. Appl. Environ. Microbiol. 71, 98-104. Goudenège, D. and Travers, M.A., Lemire A, Haffner P, Labreuche Y, Tourbiez D, Petton B, Mangenot S, Calteau A, Mazel D, Nicolas JL, Jacq A \& Le Roux F (2014) A single regulatory gene is sufficient to alter Vibrio aestuarianus pathogenicity. in press. doi: 10.1111/14622920.12699

Goulletquer, P., Soletchnik, P., Le Moine, O., Razet, D., Geairon, P., Faury, N. 1998. Summer 
mortality of the Pacific cupped oyster Crassostrea gigas in the Bay of Marennes-Oleron (France). Council Meeting of the International Council for the Exploration of the Sea Cascais (Portugal).

Green, T.J., Montagnani, C., Benkendorff, K., Robinson, N., Speck, P. 2014. Ontogeny and water temperature influences the antiviral response of the Pacific oyster, Crassostrea gigas. Fish Shellfish Immunol. 36(1),151-157.

Guillard, RRL. 1959. Further evidence of the destruction of bivalve larvae by bacteria. Biol. Bull. 117, 258-266.

Guisande, J.A., Montes, M., Farto R., Armada, S.P., Perez, M.J., Nieto T.P. 2004. A set of tests for the phenotypic identification of culturable bacteria associated with Galician bivalve mollusc production. J. Shellfish. Res. 23, 599-609.

Hara, H., Aikawa, H., Usui, K., Nakanishi, T. 2006. Outbreaks of koi herpesvirus disease in rivers of Kanagawa prefecture. Fish Pathol. 41, 81-83.

Hine, P.M. 1997. Trends in research on diseases of bivalve mollusks. Bull. Eur. Assoc. Fish Pathol. 17, 180-183.

Hine, P.M., Thorne E.T. 1997. Replication of herpes-like viruses in haemocytes of adult flat oysters Ostrea angasi: an ultrastructural study. Dis. Aquat. Org. 29, 189-196.

Hine, P.M., Wesney, B., Hay, B.E. 1992. Herpesviruses associated with mortalities among hatchery-reared Pacific oysters, Crassostrea gigas. Dis. Aquat. Org. 12, 135-142.

Keeling, S.E., Brosnahan, C.L., Williams, R., Gias, E., Hannah, M., Bueno, R., McDonald, W.L., Johnston, C. 2014. New Zealand juvenile oyster mortality associated with ostreid herpesvirus 1- an opportunistic longitudinal study. Dis. Aquat. Org. 109, 231-239.

Lacoste, A., Jalabert, F., Malham, S., Cueff, A., Gélébart, F., Cordevant, C., Lange, M., Poulet, S.A. 2001. A Vibrio splendidus strain is associated with summer mortality of juvenile 
oysters Crassostrea gigas in the bay of Morlaix (North Brittany, France). Dis. Aquat. Org. 46, 139-145.

Labreuche, Y., Soudant, P., Goncalves, M., Lambert, C. \& Nicolas, J. L. 2006a. Effects of extracellular products from the pathogenic Vibrio aestuarianus strain $01 / 32$ on lethality and cellular immune responses of the oyster Crassostrea gigas. Dev. Comp. Immunol. 30, $367-379$.

Labreuche, Y., Lambert, C., Soudant, P., Boulo, V., Huvet, A. \& Nicolas, J.-L. 2006b. Cellular and molecular hemocyte responses of the Pacific oyster, Crassostrea gigas, following bacterial infection with Vibrio aestuarianus strain 01/32. Microbes and Infection. 8, 2715-2724.

Labreuche, Y., Le Roux, F., Henry, J., Zatylny, C., Huvet, A., Lambert, C., Soudant, P., Mazel, D. \& Nicolas, J.-L. 2010. Vibrio aestuarianus zinc metalloprotease causes lethality in the Pacific oyster Crassostrea gigas and impairs the host cellular immune defenses. Fish and Shellfish Immunol. 29:753-758.

Lauckner, G. 1983. Diseases of mollusca: Bivalvia. In: Kinne, O. (Ed.), Diseases of Marine Animals Volume II: Introduction, Bivalvia to Scaphopoda. Biologische. Anstalt Helgoland, Hamburg. pp. 477-961.

Le Deuff, R.M., Nicolas, J.L., Renault, T., Cochennec, N. 1994. Experimental transmission of a herpes-like virus to axenic larvae of Pacific oyster, Crassostrea gigas. Bull. Eur. Assoc. Fish Pathol. 14, 69-72.

Le Deuff, R.M., Renault, T., Gérard, A. 1996. Effects of temperature on herpes-like virus detection among hatchery-reared larval Pacific oyster Crassostrea gigas. Dis. Aquat. Org. 24, 149-157.

Le Gall, G., Chagot, D., Mialhe, E. 1988. Branchial rickettsiales-like infection associated with a mass mortality of sea scallop, Pecten maximus. Dis. Aquat. Org. 4, 229-232.

Le Roux, F., Gay, M., Lambert, C., Waechter, M., Poubalanne, S., Chollet, B., Nicolas, J.L., 
Berthe, F.C.J. 2002. Comparative analysis of Vibrio splendidus-related strains isolated during Crassostrea gigas mortality events. Aquat. Living Resour. 15, 251-258.

Lipart, C., Renault, T. 2002 Herpes-like virus detection in infected Crassostrea gigas spat using DIG-labelled probes. J. Virol. Meth. 101, 1-10.

Lynch, S.A., Carlson, J., Reilly, A.O., Cotter, E., Culloty, S.C. 2012. A previously undescribed ostreid herpesvirus 1 (OsHV-1) genotype detected in the Pacific oyster, Crassostrea gigas, in Ireland. Parasitol . 139,1526-1532.

Martenot, C., Oden, E., Travaillé, E., Malas, J.P., Houssin, M. 2010. Comparison of two realtime PCR methods for detection of ostreid herpesvirus 1 in the Pacific oyster Crassostrea gigas. J. Virol. Methods. 70, 86-99.

Martenot, C., Oden, E., Travaillé, E., Malas, J.P., Houssin, M. 2011. Detection of different variants of Ostreid Herpesvirus 1 in the Pacific oyster, Crassostrea gigas between 2008 and 2010. Virus Res. 160, 1-2, 25-31.

Martenot, C., Fourour, S., Oden, E., Jouaux, A., Travaillé, E., Malas, J.P., Houssin, M. 2012. Detection of the OsHV-1 $\mu$ Var in the Pacific oyster Crassostrea gigas before 2008 in France and description of two new microvariants of the Ostreid Herpesvirus 1 (OsHV-1). 2012. Aquaculture. 338-341, 293-296.

Meyers, T.R. 1979. A reo-like virus isolated from juvenile American oysters (Crassostrea virginica). J. Gen. Virol.

Meyers, T.R. 1981. Endemic disease of cultured shellfish of Long Island, New York: adult and juvenile American oysters (Crassostrea virginica) and hard clams (Mercenaria mercenaria). Aquaculture. 22, 305-330.

Montes, M., Farto, R., Perez, M. J., Nieto, T. P., Larsen, J. L. \& Christensen, H. 2003. Characterization of Vibrio strains isolated from turbot (Scophthalmus maximus) culture by phenotypic analysis, ribotyping and 16S rRNA gene sequence comparison. J. Appl. Microbiol. 95,693- 
703.Moreau, P., Faury, N., Burgeot, T. \& Renault, T. 2015 Pesticides and Ostreid Herpesvirus 1 Infection in the Pacific Oyster, Crassostrea gigas. PLoS One. 10(6) e0130628.

Moss, J.A., Burreson, E.M., Cordes, J.F., Cungan, C.F., Brown, G.D., Wang, A., Wu, X., Reece, K.S., 2007. Pathogens in Crassostrea ariakensis and other Asian oyster species: implications for non-native oyster introduction in Chesapeake Bay. Dis. Aquat. Org. 77, 207233.

Nicolas, J.L., Comps, M., Cochennec, N. 1992. Herpes-like virus infecting Pacific oyster larvae, Crassostrea gigas. Bull Eur Assoc Fish Pathol 12 (1):1l-13.

Normand, J., Blin, J.L., Jouaux, A. 2014. Rearing practices identified as risk factors for ostreid herpesvirus 1 (OsHV-1) infection in Pacific oyster Crassostrea gigas spat. Dis Aquat Organ. 110 (3), 201-11.

Norton, J.H., Shepherd, M.A., Abdon-Naguit, M.R. et al. 1993a. Mortalities in the giant clam Hippopus hippopus associated with rickettsiales-like organisms. J. Invertebr. Pathol. 62, 207209.

Norton, J.H., Shepherd, M.A., Prior, H.C. 1993b. Intracellular bacteria associated with winter mortality in juvenile giant clams, Tridacna gigas. J. Invertebr. Pathol. 62, 204-206.

Oprandy, J.J., Chang, P.W., Pronovost, A.D, Cooper, K.R., Brown, R.S., Yates, V.J. 1981. Isolation of a viral agent causing hematopoietic neoplasia in the soft-shell clam, Mya arenaria. J. Invertebr. Pathol. 38, 45-51.

Paillard, C., Percelay, L., Le Pennec, M., Picard, D. 1989. Origine pathogène de 1' “anneau brun” chez Tapes philippinarum (Mollusque, bivalve). C. R. Acad. Sci. Paris 309, 235-241

Paillard, C., Le Roux, F., Borrego, J.J. 2004. Bacterial disease in marine bivalves, a review of recent studies: Trends and evolution. Aquat Living Resour. 17, 477-498.

Paul-Pont, I., Dhand, N.K., Whittington, R.J. 2013. Spatial distribution of mortality in Pacific oysters Crassostrea gigas: reflection on mechanisms of OsHV-1 transmission, DAO.127-138. 
Pépin, J.F., Riou, A., Renault, T. 2008. Rapid and sensitive detection of ostreid herpesvirus 1 in oyster samples by real-time PCR. J. Virol. Methods. 149, 269-276.

Petton, B., Pernet, F., Robert, R., Boudry, P. 2013. Temperature influence on pathogen transmission and subsequent mortalities in juvenile Pacific oysters Crassostrea gigas. Aquacult. Environ. Interact. 3, 257-273.

Peeler, J.E., Reese, R.A., Cheslett, D.L., Geoghegan, F., Power, A., Trush, M.A. 2012. Investigation of mortality in Pacific oysters associated with Ostreid herpesvirus- $1 \mu$ Var in the Republic of Ireland in 2009. Preventive Vet. Med. 105,136-143.

Pernet, F., Lagarde, F., Jeanne, N., Daigle, G., Barret, J., Le Gall, P., Quere, C., Roque D’orbcastel, E. 2014. Spatial and Temporal Dynamics of Mass Mortalities in Oysters Is Influenced by Energetic Reserves and Food Quality. PlosOne

Pokorova, D., Vesely, T., Piackova, V., Reschova, S., Hulova, J. 2005. Current knowledge on koi herpesvirus (KHV): a review. Vet. Med. Czech. 50, 139-147.

Rasmussen, L.P.D. 1986, Virus-associated granulocytomas in the marine mussel, Mytilus edulis, from three sites in Denmark. J. Invertebr. Pathol. 48, 117-123.

Renault, T. 2010. Maîtriser les maladies infectieuses pour une aquaculture durable - Les maladies infectieuses chez les mollusques, un risque à maîtriser pour une aquaculture durable, Editions Universitaires Européennes, Sarrebruk, ISBN: 978-613-1-52057-0.

Renault, T., Cochennec, N., Le Deuff, R.M., Chollet, B. 1994a. Herpes-like virus infecting Japanese oyster (Crassostrea gigas) spat, Bull. Eur. Ass. Fish Pathol. 14, 64-66.

Renault, T., Le Deuff, R.M., Cochennec, N., Maffart, P. 1994b. Herpesviruses associated with mortalities among Pacific oyster, Crassostrea gigas, in France - Comparative study. Revue Méd. Vét. 145, 735-742.

Renault, T., Lipart, C., 1998. Diagnosis of herpes-like virus infections in oysters using molecular techniques. European Aquaculture Society, Special Publication. 26, 235-236. 
Renault, T., Le Deuff, R.M., Chollet, B., Cochennec, N., Gerard, A. 2000a Concomitant herpes-like infections in hatchery-reared larvae and nursery-cultured spat Crassostrea gigas and Ostrea edulis. Dis. Aquat. Org. 42, 173-183.

Renault, T., Le Deuff, R.M., Lipart, C., Delsert,C. 2000b. Development of a PCR procedure for the detection of a herpes-like virus infecting oysters in France. J Virol Meth. 88, 41-50.

Renault, T., Lipart, C., Arzul, I. 2001. A herpes-like virus infects a non-ostreid bivalve species: virus replication in Ruditapes philippinarum larvae, Dis. Aquat. Org. 45,1-7.

Renault, T., Novoa, B. 2004. Viruses infecting bivalve molluscs. Aquat. Living Resour. 17, $397-409$.

Renault, T., Faury, N., Barbosa Solomieu, V., Moreau, K. 2011. Suppression substractive hybridisation ( $\mathrm{SSH})$ and real time PCR reveal differential gene expression in the Pacific cupped oyster, Crassostrea gigas, challenged with Ostreid herpesvirus 1. Developmental and Comp. Immunol. 35(7), 725-735.

Renault, T., Moreau, P., Faury, N.,Pepin, J.F., Segarra, A., Webb, S. 2012. Analysis of clinical Ostreid herpesvirus 1 (Malacoherpesviridae) specimens by sequencing amplified fragments from three virus genome areas. J. Virol. 86(10), 5942-5947.

Renault, T., Bouquet, A.L., Maurice J.T., Lupo, C., Blachier, P. 2014. Ostreid herpesvirus 1 infection among Pacific oyster (Crassostrea gigas) spat: relevance of water temperature to virus replication and circulation prior to the onset of mortality. AEM. 80, 5419-5426.

Romalde, J. L., Barja, J. L., 2010. Bacteria in molluscs: good and bad guys. Current Research, Technology and Education Topics in Applied Microbiology and Microbial Biotechnology. 1, $136-147$.

Romero, A., del Mar Costa, M., Forn-Cuni, G., Balseiro, P., Chamorro, R., Dios, S., Figueras, A. \& Novoa, B. 2014. Occurrence, seasonality and infectivity of Vibrio strains in natura populations of mussels Mytilus galloprovincialis. Dis.Aquat. Org. 108:149-163. 
Roque, A., Carrasco, N., Andree, K.B., Lacuesta, B., Elandaloussi, L., Gairin, I., Rodgers, C.J, Furones, M.D. 2012. First report of OsHV-1 microvar in Pacific oyster (Crassostrea gigas) cultured in Spain. Aquacult. 324-325,303-306.

Saint-Hilaire, S., Beevers, N., Way, K, Le Deuff, R.M., Martin, P., Joiner, C. 2005. Reactivation of koi herpesvirus infections in common carp Cyprinus carpio. Dis. Aquat. Org. 67, 1523.

Samain, J.F., McCombie, H. 2008. Summer mortality of Pacific oyster Crassostrea gigas. The Morest project, Eds Quae, Versailles.

Sano, M., Ito, T., Kurita, J., Yanai, T., Watanabe, N., Miwa, S., Iida, T. 2004. First detection of koi herpes virus in cultured common carp Cyprinus carpio in Japan. Fish Pathol. 39,165-167. Saulnier, D., De Decker, S., Haffner, P., Cobret, L., Robert, M., Garcia, C. 2010. A LargeScale Epidemiological Study to Identify Bacteria Pathogenic to Pacific Oyster Crassostrea gigas and Correlation Between Virulence and Metalloprotease-like Activity. Microb. Ecol. 59, 787-798.

Sauvage, C., Pépin, J.F., Lapègue, S., Boudry, P., Renault, T. 2009. Ostreid herpes virus 1 infection in families of the Pacific oyster, Crassostrea gigas, during a summer mortality outbreak: difference in viral DNA detection and quantification using real-time PCR. Virus Res. 142, 181-187.

Sawabe, T., Kita-Tsukamoto, K. \& Thompson, F. L. 2007. Inferring the evolutionary history of vibrios by means of multilocus sequence analysis. Journal of Bacteriology, 189:7932-7936. Schikorski, D., Renault, T., Saulnier, D., Faury, N., Moreau, P., Pépin, J.F. 2011 a. Experimental infection of Pacific oyster Crassostrea gigas spat by ostreid herpesvirus 1: demonstration of oyster spat susceptibility. Vet. Res. 42, 27-40.

Schikorski, D., Faury, N., Pépin, J.F., Saulnier, D., Tourbiez, D., Renault, T. 2011b. Experimental Ostreid herpesvirus 1 (OsHV-1) infection of the Pacific oyster Crassostrea 
gigas: kinetics of virus DNA detection by q-PCR in seawater and in oyster samples. Virus Res. 155, 28-34.

Segarra, A., Pepin, J.F., Arzul, I., Morga, B., Faury, N., Renault, T. 2010. Detection and description of a particular Ostreid herpesvirus 1 genotype associated with massive mortality outbreaks of Pacific oysters, Crassostrea gigas. Virus Res. 153,92-95.

Segarra, A., Mauduit, F., Faury, N., Trancart, S., Dégremont, L., Tourbiez, D., Haffner, P., Barbosa-Solomieu, V., Pépin, J.F., Travers, M.A., Renault, T. 2014. Dual transcriptomics of virus-host interactions: comparing two Pacific oyster families presenting contrasted susceptibility to ostreid herpesvirus 1. BMC Genomics. 15, 580-593 http://www.biomedcentral.com/1471-2164/15/580.

Shimahara, Y., Kurita, J., Kiryu, I., Nishioka, T., Yuasa, K., Kawana, M., Kamaishi, T., Oseko, N. 2012. Surveillance of Type 1Ostreid Herpesvirus (OsHV-1) Variants in Japan. Fish Pathol. 47 (4), 129-136.

Soletchnik, P., Le Moine, O., Faury, N., Razet, D., Geairon, P., Goulletquer, P. 1999. Mortalité de l'huître Crassostrea gigas dans le bassin de Marennes-Oléon : étude de la variabilité spatiale de son environnement et de sa biologie par un système d'informations géographiques (SIG). Aquat. Living Res. 12, 131-143.

Sun, J., Wu X. 2004. The histology, ultrastructure, and morphogenesis of the rickettsia-like organism hyperpatasited by phage particles from the oyster, Crassostrea ariakensis Gould. J. Invertebr. Pathol. 86, 77-86.

Takeuchi, T., Matsubara, T., Hirokawa, H., Tsukiyama, A., 1955. Bacteriological studies on the unusually high mortality of Ostrea gigas in Hioshima Bay-I. Bull. Jpn. Soc. Sci. Fish. 20, $1066-1070$.

Tison, D. L., Seidler, R. J. 1983. Vibrio aestuarianus - a New Species from Estuarine Waters and Shellfish. Int. J. Syst. Bacteriol. 33, 699-702. 
Tubiash, H.S., Chanley, P.E., Leifson, E. 1965. Bacillary necrosis, a disease of larval and juvenile bivalve mollusks. I. Etiology and epizootiology. J. Bacteriol. 90, 1036-1044. Tubiash, H.S., Colwell, R.R., Sakazaki, R. 1970. Marine vibrios associated with bacillary necrosis, a disease of larval and juvenile bivalve molluscs. J. Bacteriol. 103, 272-273. Tubiash, H.S., Otto, S.V. 1986. Bacterial problems in oysters. A review. In: Vivarès, C.P., Bonami, J.R., Jasper, E., eds. Pathology in Marine Aquaculture. Bredene, Belgium, European Aquaculture Society, Spec. Publ. 9, 233-242.

Vazquez-Juarez, R., Hernandez-Lopez, J., Neftali-Gutierrez, J., Coronado-Molinda, D., Mazon-Suastegui, J.M. 2006. Incidence of herpes-like virus in Pacific oyster Crassostrea gigas from farms in northwestern Mexico. In E. Palacios, C. Lora, A.M. Ibarra, A.N. MaedaMartinez, and I. Racotta (eds) Recent advances in reproduction, nutrition, and genetics of mollusks. Proceedings of the international workshop on nutrition of mollusks held at La Paz, Mexico, 6-9 November 2006.

Vezzulli, L., Pezzati, E., Stauder, M., Stagnaro, L., Venier, P. \& Pruzzo, C. 2014. Aquatic ecology of the oyster pathogens Vibrio splendidus and Vibrio aestuarianus. Environ Microbiol.

Villalba, A., Carballal, M.J., Lopez, C., et al. 1999. Branchial rickettsia-like infection associated with clam Venerupis rhomboids mortality. Dis. Aquat. Org. 36(1), 53-60.

Waechter, M., Le Roux, F., Nicolas, J.L., Marissal, E., Berthe, F. 2002. Characterization of Crassostrea gigas spat pathogenic bacteria. C. R. Acad. Sci. Paris. 325, 231-238.

Wang, Y.L., Leung, P.C., Qian, P.Y., Gu, J.D. 2006. Antibiotic resistance and plasmid profile of environmental isolates of Vibrio species from Mai Po Nature Reserve, Hong Kong. Ecotoxicology. 15, 371-378.

Waters, C.M., Bassler, B.L. 2005. Quorum sensing: cell-to-cell communication in bacteria. Annu. Rev. Cell Dev. Biol. 21, 319-46. 
Wu, X., Pan, J. 1999a. Studies on rickettsia-like organism disease of the tropical marine pearl oyster. 1: The fine structure and morphogenesis of Pinctada máxima pathogen rickettsia-like organism. J. Invertebr. Pathol. 73, 162-172.

Wu, X., Pan, J. 1999b. Studies on rickettsia-like organism disease of tropical marine peal oyster, Pinctada maxima and P. fucata: IV. On histocytopathology of RLO diseases. Acta Oceanologica Sinica. 21, 93-98.

Wu, X., Pan, J. 1999c. Studies on the Rickettsia-like organism disease of tropical marine pearl oyster: V. Ultrastructural pathology and pathogenesis of Rickettsia-like organism disease. Acta Oceanologica Sinica. 21, 113-120.

Wu, X., Pan, J. 2000. An intracellular prokaryotic microorganism associated with lesions in the oyster, Crassostrea ariakensis Gould. J Fish Dis. 23, 409-414.

Yuasa, K., Ito, T., Sano, M. 2008. Effect of water temperature on mortality and virus shedding in carp experimentally infected with koi herpesvirus. Fish Pathol. 43(2), 83-85.

Zhang, X. J., Qin, G. M., Bing, X. W., Yan, B. L. \& Liang, L. G. 2011. Molecular and phenotypic characterization of Vibrio aestuarianus, a pathogen of the cultured tongue sole, Cynoglossus semilaevis Gunther. J. Fish Dis. 34, 57-64. 


\section{FIGURE LEGENDS}

Figure 1 - OsHV-1 and its variants in association with mortality in bivalve molluscs

Figure 2 - First reports of isolation of Vibrio aestuarianus in the USA (Tison and Seidler 1983), Hong Kong (Wang et al. 2006), France (Garnier et al. 2007and 2008, Saulnier et al. 2010, Azebengbé et al. 2010), Spain (Romero et al. 2014 and Goudenège et al., under review), Italie (Vezzulli et al., 2014 and Goudenège et al.,2014), New Zealand (Keeling et al. 2014), Ireland (Cheslett et al. 2014).

Figure 3 - Location of the main target areas for the primary analysis of the genetic diversity of OsHV-1: "C region", ORF 4 and the C2/C6 primer set (adapted from Arzul et al., 2001 and Davison et al., 2005). 


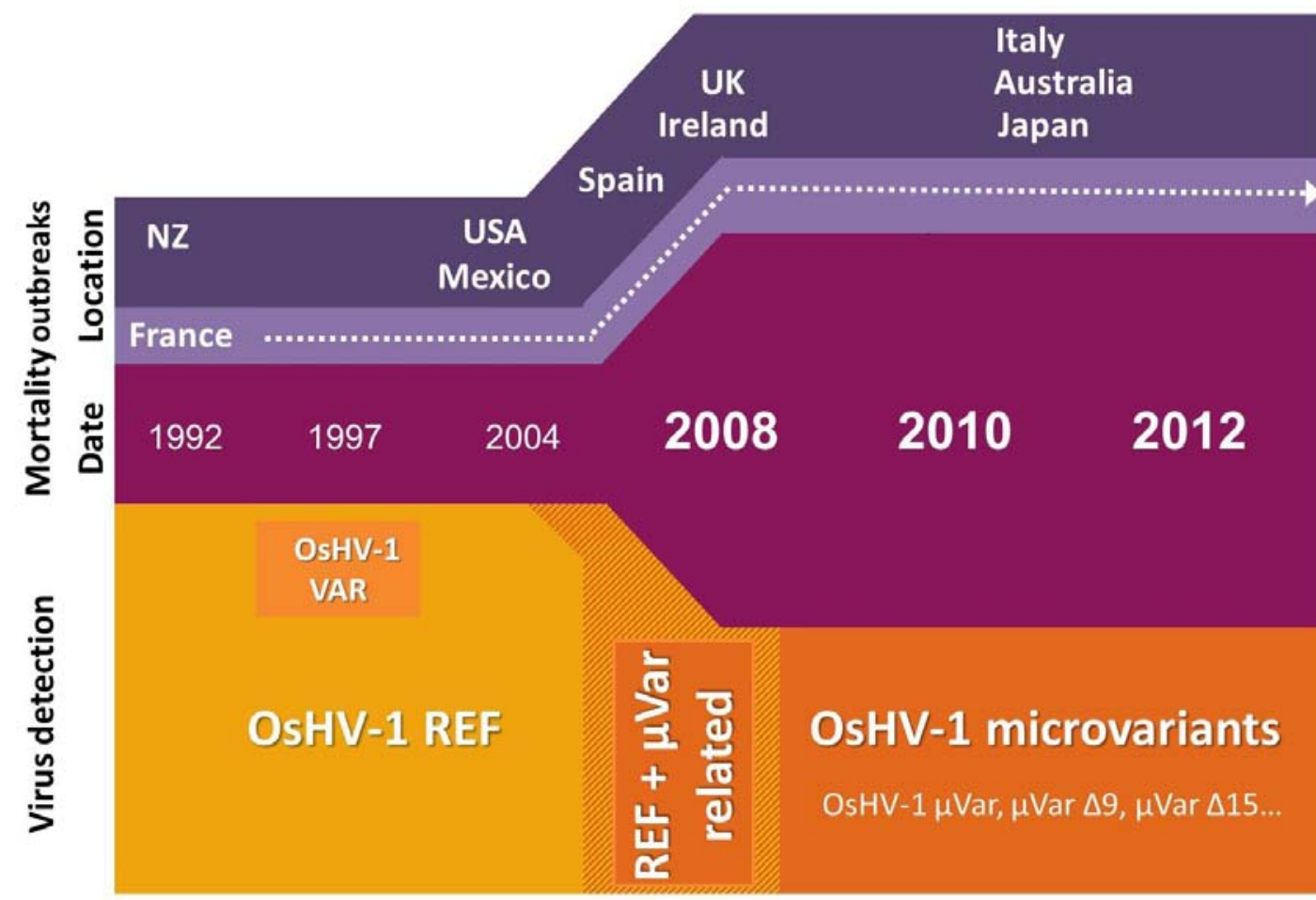


First reports of isolation of $V$. aestuarianus

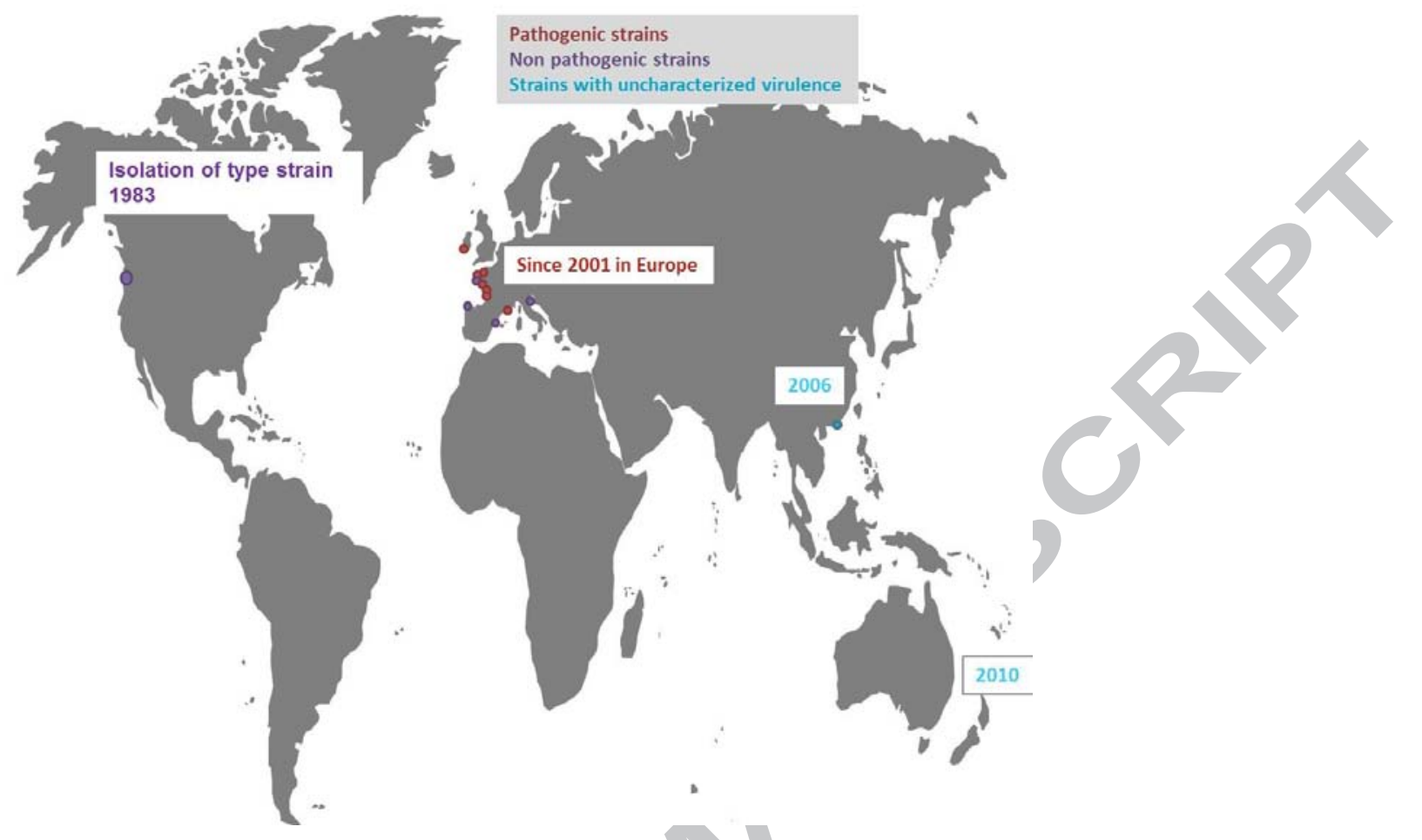




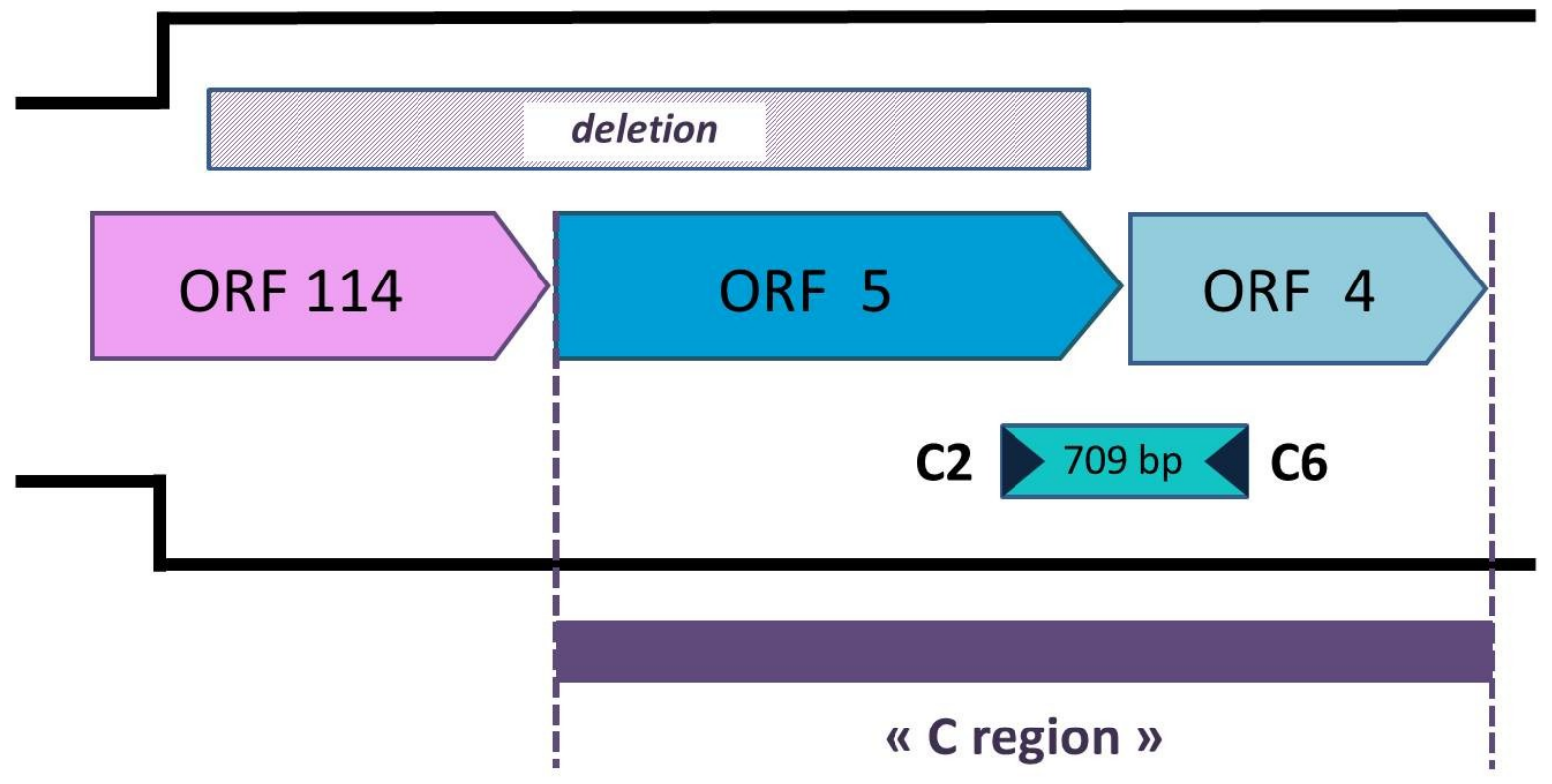

